\title{
SLUDGE AND WASTE WATER APPLICATION FOR ENERGY PLANTATION - CASE STUDY FROM LODZ REGION IN POLAND
}

\author{
Agnieszka Karczmarczyk \\ Hubert Komorowski \\ Józef Mosiej \\ Warsaw Agricultural University-SGGW, Poland
}

\begin{abstract}
Within renewable energy sources available in Poland, biomass seems to have the largest potential, estimated to $90 \%$. About $70 \%$ of renewable energy should be obtained from agricultural production of energy plants. Climatic conditions in Poland (vegetation period of 210-215 days and precipitation of 500-700 $\mathrm{mm}$ ) are profitable for willow plantation. The natural productivity can be as high as $14 \mathrm{Mg} \mathrm{d}$.m. per ha. However, the productivity can be increased by using waste water for irrigation and sludge for fertilisation.
\end{abstract}

For decades an area of 4500 ha of Ner River valley was used as a part of municipal wastewater treatment system for Lodz city. The valley has specific soil-water conditions with deep sandy alluvial soils and shallow groundwater table. During the irrigation process the inflow of wastewater on an artificially formed border check infiltrates into the soil and fills the available porosity.

Average outflow from wastewater treatment plant in Lodz $\left(2 \mathrm{~m}^{3} / \mathrm{s}\right)$ and sludge daily production of $30-35 \mathrm{Mg} \mathrm{d}$. m. (app. $170 \mathrm{Mg}$ dewatering sludge) can be utilised on energy biomass plantation ( e.g. Salix Viminalis or grasslands) located in the Ner River valley.

\section{KEYWORDS}

Short rotation plantation; Irrigation; Fertilisation; Willow; Renewable energy; Recycling of nutrients

\section{SHORT ROTATION PLANTATION (SRP) IN POLAND}

Within renewable energy sources available in Poland, biomass seems to have the largest potential, estimated to $90 \%$. About $70 \%$ of renewable energy should be obtained from agricultural production of energy plants. Predicted energy use in present year is approximated to $4000 \mathrm{PJ}$, in which $87 \mathrm{PJ}$ should be produced from energy plants. Making assumption that 1 ha of short rotation plantation (SRP) gives about $310 \mathrm{GJ}$ of energy, over 200 thousand ha of SRP is needed to reach the goal for 2005 . To reach the goal of the $9 \%$ share of renewable 
energy sources in energetic balance of Poland in 2010 and assuming annual energy needs for $5000 \mathrm{PJ}$, about 600 - 1000 thousands ha of SRP will be needed [7].

Climatic conditions in Poland (vegetation period of 210-215 days and precipitation of 500$700 \mathrm{~mm}$ ) are profitable for willow plantation and other plants cultivation. The natural productivity of willow can be as high as $14 \mathrm{Mg} \mathrm{d.m}$. per ha. However, the productivity can be increased by using irrigation and fertilisation.

According to recent data of Polish Ministry of Agriculture and Rural Development (MRiRW) about 5.5 thousand hectares of Salix plantations (over 500 plantations) is established in Poland. However those data do not cover the real area of SRP, because does not include plantations which produce biomass for farm internal needs (eg. heating farmstead buildings, etc.) and many small plantations (of area less than $1 \mathrm{ha}$ ).

\section{Advantages of SRP:}

- Lower cost of energy (1/3 of cost compared with coal)

- Possible sludge utilisation (over 360 thousands $\mathrm{Mg}$ of d.m. sludge is produced every year)

- Possible wastewater tertiary treatment

- Workplace (1 person taking care of 20 ha plantation will eam 3750 Euro a year)

- Cost biomass production (235 Euro per ha) - subvention (55 Euro per ha) - price of biomass 25 Euro per $\mathrm{Mg}$ of d.m. ${ }^{*} 14 \mathrm{Md}$ d.m. $=$ profit of about 235 Euro per ha.

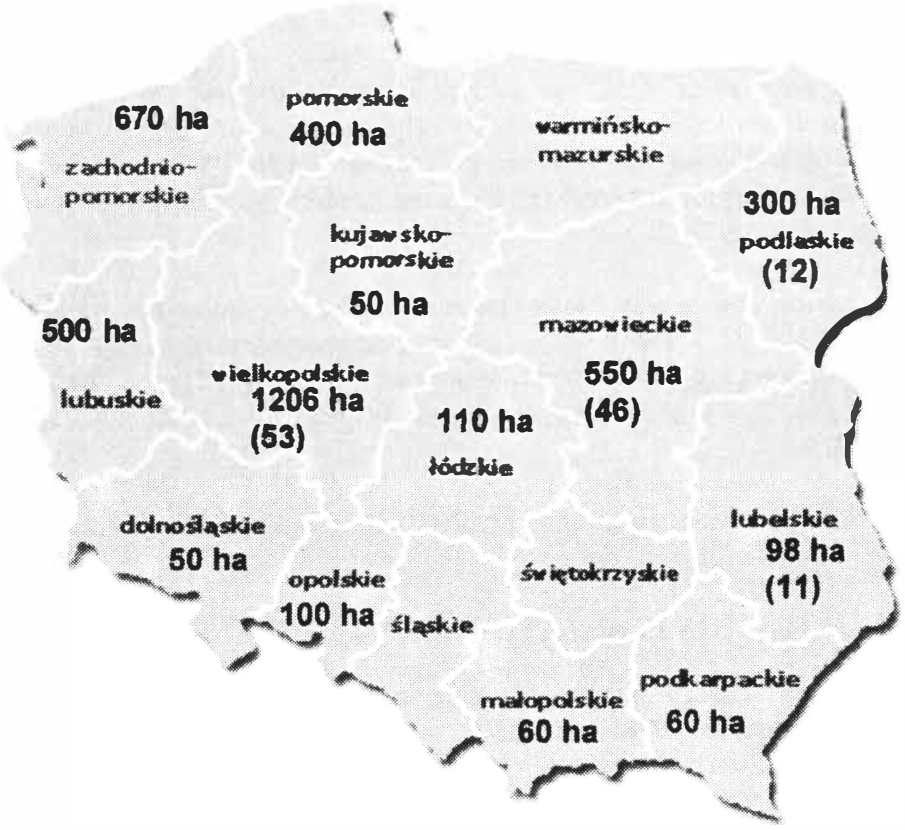

Figure 1. Woiewodships with the largest and the lowest Salix plantations area. Number of plantations shown in brackets. Based on official data from MRiRW (in black) and other sources (in blue). 


\section{Problems with implementation of SRP:}

- Salix plantations in Poland are not subsidised from EU sources.

- EC gave consent to appropriation of 55 thousands Euro from the national budget. It gives only 10 Euro per ha of SRP (direct subventions to agricultural cultivated area amounts 55 Euro per ha).

- Only two energy plant species Salix sp. and Rosa multiphlora var. can be subsidised.

- To get subvention the farmer has to sign long term agreement with biomass recipient, who is concerned with conversion of biomass to the source of energy (fuel).

- High costs of installation modernisation

\section{Other significant energy biomass sources in Poland}

Among other biomass sources, straw and hay may play significant role as a source of energy. Surplus mass of straw in Poland is estimated on 9-12 mln Mg per year what gives technical potential of 195 PJ. It is a cheapest available fuel. However, installations for combustion of straw are very expensive. Actually, only $1 \%$ of produced straw (25 mln Mg per year) is used as an energy source.

The oldest biomass source of energy is wood. Mass of wood available for use as a fuel amounts 8,8 mln Mg per year (technical potential 57,6 PJ). According to ECBREC in 2002 in Poland wood biomass was used in both large $(>500 \mathrm{~kW}-180$ installations $)$ and small $(<500$ $\mathrm{kW}-110$ thousands installations) heating plants.

The other available biomass source of energy is biogass produced from manure, sludge or wastes stored on landfills. Technical potential of biogass from manure is estimated on 37,5 PJ. Additional $100 \mathrm{PJ}$ can be obtained from wastewater sludge and similar potential from landfills. However, production of biogass from sludge can be profitable, if the volume of treated wastewater is higher than 20 thousands $\mathrm{m}^{3}$ per day. Dried and bicket sludge $(90 \%$ of d.m.) can also be used as a fuel in burning process (potential of 9,2 $\mathrm{MJ}$ per $\mathrm{kg}$ ).

\section{Water and nutrient sources for energy biomass production}

Sludge produced in the wastewater treatment process can be used as a source of energy not only directly, as mentioned above. It can also be used as a source of nutrients for energy biomass production if applicated as fertiliser on SRP. The actual annual production of sludge approximates 360 thousands $\mathrm{Mg}$ of d.m. Predicted number of produced sludge in near future is about 420 thousand $\mathrm{Mg}$ of dry matter within a year. On 1 ha of SRP up to $10 \mathrm{Mg}$ of sludge can be utilised. It can bring to the farmer additional income of about 35 PLN per $\mathrm{Mg}$ of sludge. The availability of sludge for SRP is high, because only $7.5 \%$ of produced sludge reaches the chemical norms for agricultural use.

Wastewater itself can also be non expensive and easy available source of nutrients and water for SRP. At the end of 2004 over 2000 wastewater treatment plants was operated, with average flow between 50 and $100000 \mathrm{~m}^{3} \mathrm{~d}^{-1}$. The number of people connected to those plants was over $20 \mathrm{mln}$. In treated wastewater about 29,4 thousands $\mathrm{Mg}$ of organic pollutants $\left(\mathrm{BOD}_{5}\right)$ and 3,1 thousands $\mathrm{Mg}$ of phosphorus is discharged to receivers during the year. Using wastewater for SRP irrigation and fertilisation would advantage in joined treatment and high and stable biomass production. 


\section{SITE DESCRIPTION}

According to the water framework directive highly degradated rivers must aim to reach "good ecological status" until 2015. In some regions technical solutions like building wastewater treatment infrastructure could be not sufficient due to high concentration of wastewater amount in small region without large enough receiving water body. The example can be Lodz region, where the total amount of wastewater discharged is as high as $2 \mathrm{~m}^{3}$ per second compared with 10 times lower receiver natural flow. This wastewater - river water ratio is too high to make possible reaching the good status of the river ecosystem without enormous expenditure of money, chemicals and energy spending on treatment process. Even if it's possible from technical point of view it doesn't make sense because in most treatment plant investment, the self-purification process is taken under consideration as the last step of treatment. That makes it to be cost-effective and keeps the social costs of treatment acceptably low, what is one of assumptions of sustainable development. But the Ner River seems to have lost the ability of self-purification. The contaminants which are stored in bed sediments and irrigated valley soil could be released slowly causing internal contamination.

Ner River is small lowland river of $0,2 \mathrm{~m}^{3}$ natural flow. The city of Lodz discharges $2 \mathrm{~m}^{3} / \mathrm{s}$ of wastewater and for decades Ner was the receiver of such amount crude wastewater. Therefore the river average concentration of nitrogen amounted to $23 \mathrm{mgN} / \mathrm{L}$ and phosphorus 11,6 mgP/L (loads: 2898 tons N/year and 1462 tons P/year respectively). The self purification was mainly effected by irrigation of grasslands in the valley (about 4500 hectares) what gave more than 1300 tons of nitrogen and about 200 tons of phosphorus removed with the yield.

The valley has specific soil-water conditions with deep sandy alluvial soils and shallow groundwater table. During the irrigation process the inflow of waste water on an artificially formed border check infiltrates into the soil and fills the available porosity. Excess of water flows as surface runoff towards open drainage ditches (see Figure 2). The natural soil-plant system is a dynamic medium for absorbing, treating and utilising the wastewater constituents. It works as a mechanical, chemical and biological filter, which is renewed through systematic agricultural use. The research made by Matczak [9] showed that irrigation system made significant contribution to reduction of nutrients and other pollutants. In wastewater flowed through irrigation system reduction of nitrogen ranged from 33 to $89 \%$, phosphates - from 23 to $91 \%$, potassium and BOD respectively: $24-66 \%$ and $50-77 \%$. Unfortunately, in some areas, wastewater irrigation effected also in contamination of soil with hazardous metals. The role of sewage irrigation, however controversial with its side effects of soil contamination, was invaluable for lower rivers ecosystems like Warta and Odra. It was the most important factor which reduces the enormous load of contaminant flowing through the Ner River. We should emphasise that relatively small Ner in 1996 was a receiver of 3,5\% of total sewage from Poland. Therefore its impact on pollutants load to Baltic Sea was significant. 

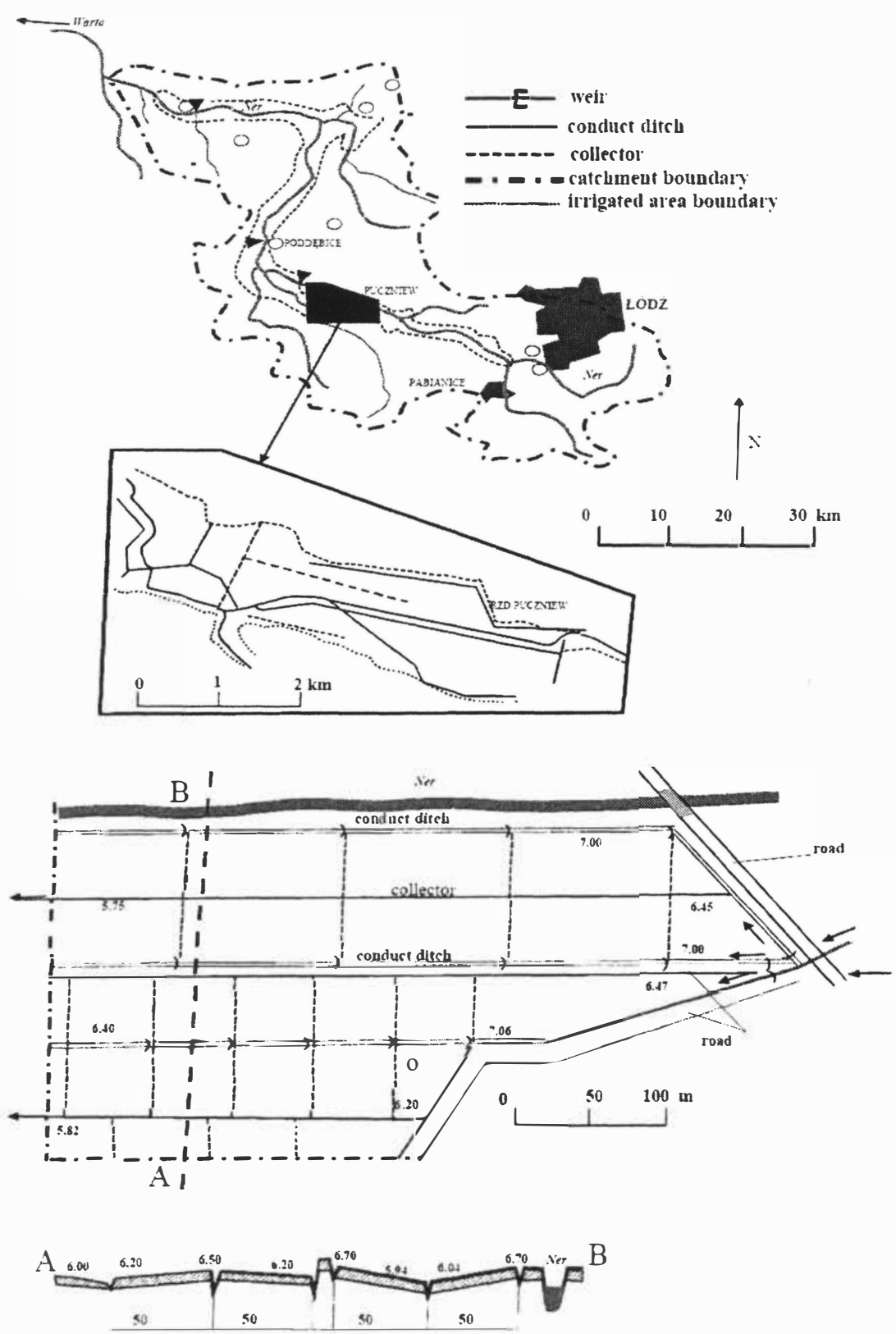

Figure 2. Ner river drainage catchment, range and scheme of irrigation system $[10,11]$. 


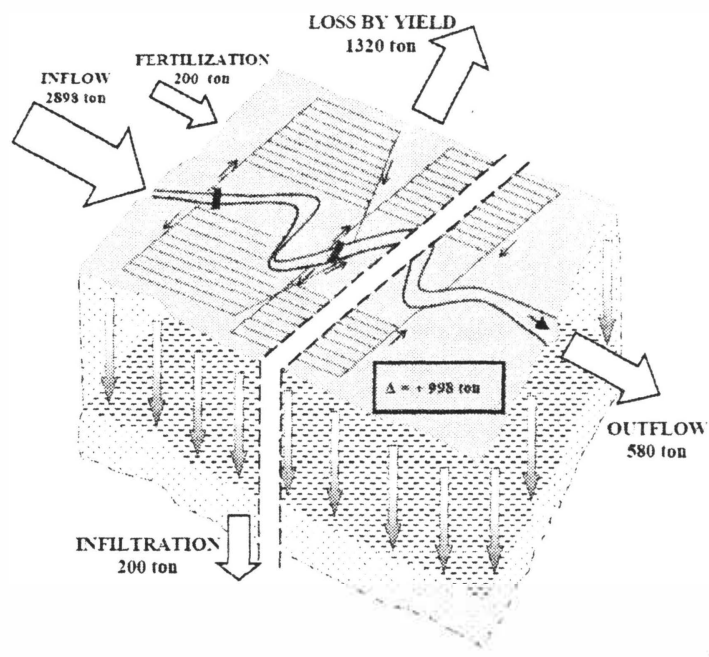

Figure 3. Total nitrogen balance in the Ner river valley irrigation system $[10,11]$.

In late ' 90 the treatment plant was started up and the water quality, however much better, still didn't reach satisfactory level - most of chemical parameters remain high and the water is still classified in 5 - the worst quality range. The wide irrigation system existing in the river valley is still used but because of regress in agriculture the production is not as intensive as in the past. The main purpose of this system was to produce fodder for animals. The results of many investigations made in the valley have shown that average reduction of nitrogen and phosphorus in irrigation system amounted to $80 \%$ and $78 \%$ in the valley scale (see Figure 3 and Figure 4) $[10,11]$. At present the inflow is much lower and percentage reduction could not be so high, however it remain very important factor in river restoration.

When wastewater irrigation is used distribution of pollutants could be wide and prospective need of reclamation possible $[1,4]$. But ecological effect of nutrients recycling shouldn't be passed over. Many scientists point out that using waste water, which are rich in nutrients for irrigation, is one of the right solution $[5,8]$. The role of closing nutrients cycling in the environment, as the way of making environment sustainable, is more and more often described in the literature [2]. The constructed wetlands which are often used for purification are a good example.

The form and the way of nutrients distribution should be discussed. It could be done, obviously, in two ways: wastewater irrigation and fertilisation with sludge. But if irrigation is needed anyhow - we can use irrigation system as the another wastewater treatment step and bring sludge fertiliser as nutrients source separately. It seems not to be very cost-effective and sustainable solution of wastewater and sludge problem. 


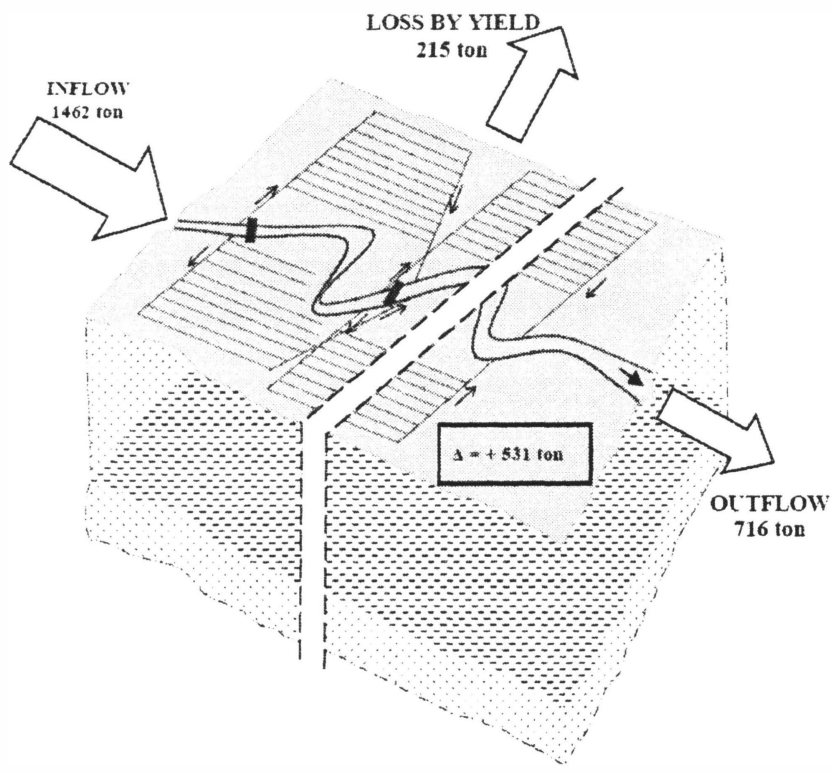

Figure 4.Total phosphorus balance in the Ner river valley irrigation system [10,11].

\section{SLUDGE UTILIZATION AND ENERGY PLANTATION}

Treating wastewater in WWTP (Wastewater treatment plant of Lodz) result in production of surplus sludge which is difficult to utilise. Using sludge as a fertiliser and for degradated soil restoration in many cases gave very good results. The content of nutrients and organic matter in sludge from treatment plant is higher than in commonly used manure. The nutrients are released slowly and easy to absorb by plants. But sludge can also contain harmful chemicals (especially heavy metals), pathogens and parasites what depends on genesis of the sludge and type of purification process.

Polish and EU law characterise sludge which could be used as a fertiliser for agriculture and non-food plantation. The limit concentrations of hazardous metals are shown in Table 1 . As shown in the table, the sludge from WWTP meets all conditions to be used for non-food plantation and for restoration as well. But critical factor is also in this case is metal concentration in soil. This limitation, according to Liwski studies [6], could be the main obstacle for sludge utilisation in this way especially in most contaminated profiles located near WWTP like Konstantynów but also Jezew. Polish law specify also dose of sludge that could be applied as a fertiliser. According to the law the first dose is as height as $250 \mathrm{Mg}$ d.w. per hectare and it could be applied during first 3 years and next years sludge disposing is limited to $10 \mathrm{Mg}$ per hectare. 
Table 1. The limit contents of metals in sludge which could be use as fertiliser [11].

\begin{tabular}{llllll}
\hline Metal & $\begin{array}{l}\text { Average } \\
\text { content } \\
\text { sludge } \\
\text { WWTP plant }\end{array}$ & $\begin{array}{l}\text { Limit metal contents [mg per kg dry weight of sludge] } \\
\text { fhen using for: }\end{array}$ & \\
\hline \multicolumn{7}{c}{ Agriculture } & $\begin{array}{l}\text { Restoration non- Non-food plantation } \\
\text { agriculture land }\end{array}$ & $\begin{array}{l}\text { EU D } \\
1986 / 276 / \text { EEC }\end{array}$ \\
\hline lead & 57 & 500 & 1000 & 1500 & $750-1200$ \\
\hline cadmium & 5,8 & 10 & 25 & 50 & $20-40$ \\
\hline mercury & 3,2 & 5 & 10 & 25 & $16-25$ \\
\hline nikel & 138 & 100 & 200 & 500 & $300-400$ \\
\hline zinc & 1553 & 2500 & 3500 & 5000 & $2500-4000$ \\
\hline copper & 413 & 800 & 1200 & 2000 & $1000-1750$ \\
\hline chromium & 207 & 500 & 1000 & 2500 & - \\
\hline
\end{tabular}

The main advantage of using sludge as fertiliser is lower fertiliser purchase costs or even profits: the treatment plants administration pays sludge receivers for sludge utilisation from 30 to 100 PLN for Mg of dry weight.

Willow Salix viminalis is one of several plants used on energy plantation and wastewater treatment [3] and it seams to be the best for studied case. Water demand of this plant is high, so it could be cultivated on irrigated parts of Ner valley even if heavy metal-contaminated [13]. As a non-food plantation it could be also fertilised with the sludge contaminated with heavy metals. To get 20 tones per hectare crop of willow dry biomass the plant need about $150 \mathrm{~kg}$ of nitrogen, $18 \mathrm{~kg}$ of phosphate and $60 \mathrm{~kg}$ of potassium [12], therefore we should to estimate available nutrients content in soil, sludge and irrigation water. However priority of this plantation could be sludge and sewage utilisation and heavy metals phytoremediation not only biomass production.

WWTP of Lodz produces about $35 \mathrm{Mg}$ of sludge dry weight daily. If we assume that during 20 years of using willow plantation for sludge utilisation we bring in $250 \mathrm{Mg} / \mathrm{ha}$ for land reclamation during first 3 years and $10 \mathrm{Mg} / \mathrm{ha}$ each next year. We can utilise total amount of $420 \mathrm{Mg}$ sludge per hectare. It results in $21 \mathrm{Mg} / \mathrm{ha}$ per year average. To utilise all sludge produced at WWTP will be need about 650 hectare of willow plantation. Without first reclamation dose, applying only $10 \mathrm{Mg} /$ ha per year, the area need for sludge utilisation would amount 1300 hectare. Both scenarios are possible to implement because estimating area available for setting up willow plantations is 4000 hectares.

\section{CONCLUSIONS}

1. Short rotation plantations (SRP) represent an economic solution for high efficient biomass production and low-cost wastewater and sludge treatment, on the other hand they can contribute to the local independence from external fossil fuels and their price fluctuation, to less environmental pollution and more local employment.

2. Before qualify the area where energy plantation could be set up and area for sludge fertilisation, determination of soil condition is needed. The areas where the hazardous metals concentration limits in the soil are exceeded could be use for energy plantation but without sludge fertilisation. In this cases nutrients should be provided with irrigation only. 
The concentration of willow plantations in relatively small area will effect with establishing industrial infrastructure for willow biomass processing and distribution and make it much more cost-effective way to provide renewable energy in this region.

3. Selection of the areas for sludge utilisation should be proceeded by heavy metals content soil analysis. At the areas where limits are exceeded (industrial areas according to classification) recultivation is needed. This kind of areas in Ner river valley occurred locally, on small surfaces, mainly in local depressions where the sludge has been accumulated during winter irrigations.

4. The irrigation system in Ner river valley was for decades the most important factor of reducing the river pollution. Huge amount of nutrient was removed with the yield before reached the river mouth but on the other hand the big amount of contaminants left in the soil and make it locally useless for food production. In the age of Water Framework Directive and the new standards of environmental protection the changes in land use are needed but the irrigation system should be used continuously. It must be included in a new vision of river basin management.

5. The main changes should be applied to plant and agriculture production structure in the valley. On the metal contaminated area energy plantation should be established, and part of area which meets requirements could be used for sludge fertilisation. It could solve the problem of sludge from WWTP storing. Additionally the irrigation with Ner river water will improve the water quality and moisture soil condition needed for willow growing.

\section{ACKNOWLEDGEMENTS}

Acknowledgements are made to the Rector of WAU for financing the project "Use of waste water and sludge for SBR irrigation and fertilisation". Financial support was also received from 6 FP EU within the WACOSYS project.

\section{REFERENCES}

[1] Biernacka E., 1970. Wpływ nawodnień wodami ściekowymi na zawartość mikroelementów w glebach mineralnych i torfowych (Influence of waste water irrigation for microelements contents in mineral and organic soils). Rocz. Nauk Roln. Ser. F, t. 77, z. 4, 545-568 (in Polish).

[2] Boyden B.H., Rababah A.A., 1995. Recycling nutrients from municipal wastewater. Desalination 106, 241-246

[3] Hasselgren K., 1998. Use of municipal waste products in energy forestryo highlights from 15 years of experience. Biomass and Bioenergy 15(1), 71-74,

[4] Hemkens D.J., Kemp A., Brekhoven L.W., 1980. Accumulation of heavy metals in the soil due to annual dressing with sewage sludge. Neth. Jour. Agric. Scie. 28(4), 228-237

[5] Labrecque M., Teodorescu T. I., 2001. Influence of plantation site and wastewater sludge fertilisation on the performance and foliar status two willow species grown under SRIC in southern Quebec (Canada). Forest Ecology and Management 150, 223-239

[6] Liwski S., Matyjasik Z., Litwiński J., 1989. Problem of heavy metals in the Ner river valley. In_Proceedings of Polish - Hungarian Seminar "Sewage and sludge treatment and utilisation in the soil". SGGW-AR, pp 75-87.

[7] Ludwicki A., 2005. Rolnictwo jako źródło odnawialnej energii (Agriculture as a source of renewable energy). In: Polska wieś 2025 (Polish village 2025), pp.183-190 (in Polish). 
[8] Mant C., Peterkin J., May E., Butler J., 2003. A feasibility study of a Salix viminalis gravel hydroponic system to renovate primary settled wastewater. Bioresource Technology 90, 19-25.

[9] Matczak A., 1998. Ocena możliwości i skutków środowiskowych doczyszczania wód ściekowych $\mathrm{z}$ oczyszczalni ścieków $\mathrm{w}$ Lodzi poprzez nawodnienia $\mathrm{i}$ inne prace ochronne. (Possibilities and environmental assesment of outflow from WWTP in Lodz by irrigation and other protection activities). MSc Thesis. Department of Environmental Improvement, Warsaw Agricultural University (in Polish).

[10] Mosiej J. Karczmarczyk A., 2001. Ecological Engineering for Ner River water quality improvement - possible solutions. Ann. Warsaw Agricult. Univ. - SGGW, Land Reclam 31, pp.75-86

[11] Mosiej J.,1999. Przyrodniczo- techniczne uwarunkowania gospodarowania woda w dolinie rzek Ner (Environmental and technical conditions of water management in Ner river valley). Rozprawy Naukowe i Monografie 222, Wyd. SGGW (in Polish).

[12] Pertu K., 1993. Plantacje energetyczne - produkcja energii oraz detoksykacja ścieków i osadów ściekowych (Energy plantaion - production of energy with waste water and sludge utilisationo). Aura 3, 10-16 (in Polish).

[13] Pulfold I.D., Watson C., 2003. Phytoremediation of heavy metal-contaminated land by trees-a review. Environment International 29, 529-540 